 \\ INSTITUTE OF GEOGRAPHY AND SPATIAL ORGANIZATION \\ POLISH ACADEMY OF SCIENCES \\ www.igipz.pan.pl \\ www.geographiapolonica.pl
}

\title{
EFFECT OF A SMALL DAM RESERVOIR ON THE WATER TEMPERATURE IN A CARPATHIAN RIVER
}

\author{
Łukasz Wiejaczka ${ }^{1}$ - Katarzyna Wesoły ${ }^{2}$ \\ ${ }^{1}$ Institute of Geography and Spatial Organization \\ Polish Academy of Sciences \\ Św. Jana 22, 31-018 Kraków: Poland \\ e-mail: wieja@zg.pan.krakow.pl \\ ${ }^{2}$ Regional Water Management Board in Kraków \\ Marszałka Józefa Piłsudskiego 22, 31-109 Kraków: Poland \\ e-mail: kwesoly@krakow.rzgw.gov.pl
}

\begin{abstract}
The article presents the evolution of water temperature changes in the Wisłok river (the upper Vistula basin) as an effect of Besko reservoir, existing since 1978, with a capacity of 15 million $\mathrm{m}^{3}$. The thermal effect of this small Carpathian reservoir is compared to that of larger reservoirs located in the region. As has been found in the analysis, the direction (increase or decrease) of the annual water temperature variations in the Wisłok as a consequence of the thermal conditions in the reservoir is the same as in other Carpathian rivers downstream of larger reservoirs. On the other hand, the scale of that effect is much smaller and it is observable in a shorter section of the river compared to other rivers with reservoirs. Therefore, the thermal effects of Besko reservoir may be considered of little significance for the natural environment.
\end{abstract}

\section{Key words}

water temperature $\cdot$ dam $\bullet$ reservoir $\bullet$ river $\bullet$ Carpathians

\section{Introduction}

The thermal regime of rivers plays an important role in the overall health of aquatic ecosystems, including water quality issues and the distribution of aquatic species within the river environment (Caissie 2006). Changes in the thermal regime of rivers are among the most pronounced and significant hydrological consequences of the construction of dams and creation of reservoirs on rivers. Seasonal thermal stratification of water in a reservoir results in significant changes in the river's thermal regime depending on the season, i.e. the river water becoming cooler or warmer than it would be if no reservoir was present (e.g. Liu et al. 2005; Olden \& Naiman 2010; Soja \& Wiejaczka 2014). The key issue which requires explanation in research into the effect of reservoirs on the water temperature 
patterns in rivers downstream of the dams is the direction (warming or cooling) of that effect, its scale and spatial extent, and the reasons of the changes observed (Wiejaczka et al. 2015). Thermal effects of river regulation by dams vary depending on the landscape position of the dam, the mode of dam operation, the release depth and the environmental and geomorphologic setting as well as the hydrotechnical parameters of the reservoir (Olden \& Naiman 2010; Wiejaczka et al. 2015).

In the international literature, the issue of the changes of river thermal regimes downstream of reservoirs is often explored in the context of hydrobiology research (e.g. Webb \& Walling 1993; Lessard \& Hayes 2003; Frutiger 2004) as water temperature is an important factor regulating biological life in rivers (Allan \& Castillo 2007). In Poland, most of the research in this area has been conducted in the Carpathian rivers, i.e. the Dunajec with the reservoir complexes Rożnów-Czchów (e.g. Chomiak 1962; Tomik 1969; Cyberska 1972, 1975; Punzet 1991) and Czorsztyn-Sromowce Wyżne (Wiejaczka et al. 2015) as well as the Ropa river with the Klimkówka reservoir (e.g. Wiejaczka 2011; Soja \& Wiejaczka 2014).

Within Poland, large reservoirs are particularly concentrated in the Carpathians (in the drainage basin of the upper Vistula river), with about a dozen dam reservoirs classified as large by the ICOLD (International Commission of Large Dams). Their key purpose is retention of water for rational management of water resources. The Carpathian reservoirs serve primarily for reducing floods, increasing minimum discharges and eliminating low waters, as well as supply of potable and industrial water and electricity generation (Wiejaczka 2010).

One of the reservoirs in the Polish Carpathians is Besko reservoir, created on the Wisłok river in 1978 (Fig. 1). The effect of Besko reservoir on the thermal regime of the Wistok has not thus far been subject of research. It is however important to undertake such research as Besko reservoir is one of the smallest large hydrotechnical facilities in the Polish Carpathians. While the effect of larger facilities in the
Polish Carpathians, be it single reservoirs (Klimkówka) or reservoir complexes (Czorsztyn-Sromowce Wyżne and Rożnów-Czchów), on river temperature patterns has already been explored (as described in the publications quoted above), the effect of a smaller reservoir has not yet been analysed.

The objective of this study is demonstrating the effect of Besko reservoir on the changes of the Wisłok thermal regime and comparing the thermal effect of this small Carpathian reservoir to that of larger reservoirs located in mountain areas.

\section{Research subject}

The Wisłok river is a left-bank tributary of the San river, with a total length of $219.7 \mathrm{~km}$, of which $30 \mathrm{~km}$ is upstream and $184 \mathrm{~km}$ is downstream of the Besko reservoir dam (Fig. 1). In its upper course, the Wisłok drains the eastern part of the Beskid Niski (Low Beskid) mountains; in its middle course, it flows across the Bukowsko Upland and the Jasło-Sanok Basin, and in its lower course, across Sandomierz Basin. According to Dynowska (1971), the Wisłok river regime, with its rain, groundwater and snow feeding, is transitory between Western Carpathian rivers, characterised by marked summer floods as well as spring floods, and those of the Eastern Carpathians, which do not have a summer flood but a main flood in spring and a secondary in winter.

The Besko reservoir dam is located at $183.9 \mathrm{~km}$ point of the Wisłok course. The total capacity of the reservoir is up to $15 \mathrm{mil}$ lion $\mathrm{m}^{3}$, its surface is $1.26 \mathrm{~km}^{2}$ at the maximum water level (336.00 m a.s.l.) and its maximum depth is $30 \mathrm{~m}$. The reservoir has two main branches: one in the Wisłok valley (approx. $5 \mathrm{~km}$ long) and the other in the Czernisławka river valley (approx. $2.5 \mathrm{~km}$ long). The key purpose of creating the reservoir was to increase the minimum discharge of the Wisłok downstream from the dam in order to protect the wildlife and to ensure water supply for residents, mainly in the town of Krosno. The guaranteed outflow from the reservoir, under 


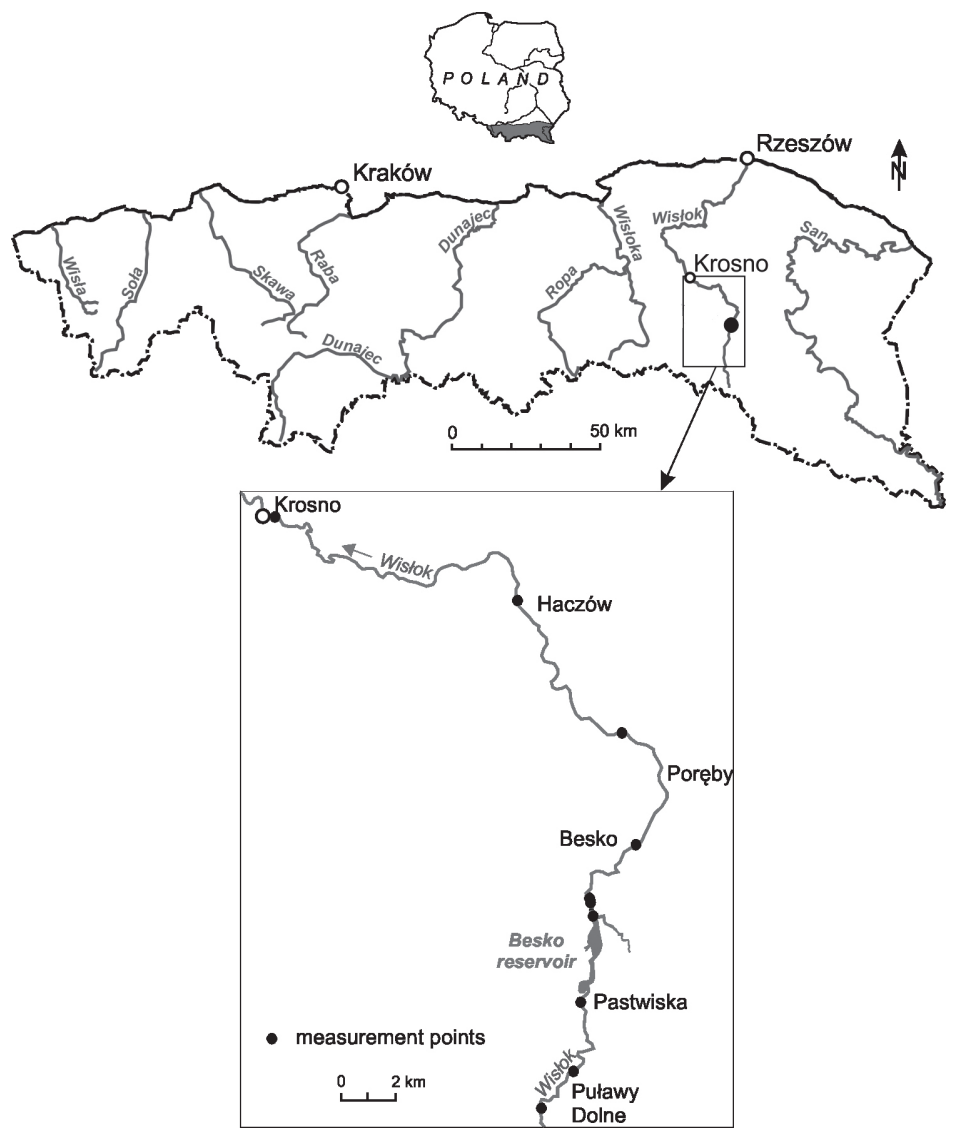

Figure 1. Area of the research and the measurement locations

normal operating conditions, is $0.9 \mathrm{~m}^{3} \cdot \mathrm{s}^{-1}$. Flood protection is a secondary purpose.

Under normal operating conditions, water is flowing out from the reservoir through: a biological water pipeline (with a capacity of 0.20 to $0.31 \mathrm{~m}^{3} \cdot \mathrm{s}^{-1}$ ) from the depth of approx. $310.00 \mathrm{~m}$ a.s.l. directly to the stilling basin; the outflow channel of the Small Hydropower Plant (with an average capacity of $0.20 \mathrm{~m}^{3} \cdot \mathrm{s}^{-1}$ ) from the depth of $324.50 \mathrm{~m}$ a.s.l. directly to the stilling basin; and the pipeline of the Wisłok Fish Farm (with a capacity of up to $0.30 \mathrm{~m}^{3} \cdot \mathrm{s}^{-1}$ ) directly to the Wisłok river channel approx. $400 \mathrm{~m}$ downstream of the dam.

According to Wiejaczka and Wesoły (2012), for most of the year, the discharge from Besko reservoir is maintained at the level of the guaranteed discharge. An analysis of average monthly inflows to Besko reservoir shows that there are three periods of increased discharge on the Wisłok over the year. The first period, with maximum inflow values, is in March $\left(6.70 \mathrm{~m}^{3} \cdot \mathrm{s}^{-1}\right)$ and April $\left(6.57 \mathrm{~m}^{3} \cdot \mathrm{s}^{-1}\right)$, starting already in February $\left(3.51 \mathrm{~m}^{3} \cdot \mathrm{s}^{-1}\right)$. The second period, with significantly lower maximum inflows, is in July $\left(4.96 \mathrm{~m}^{3} \cdot \mathrm{s}^{-1}\right)$ and the third is in September $\left(3.32 \mathrm{~m}^{3} \cdot \mathrm{s}^{-1}\right)$. Low inflows to Besko reservoir are observed mainly in autumn and winter, between October $\left(2.14 \mathrm{~m}^{3} \cdot \mathrm{s}^{-1}\right)$ and January $\left(2.85 \mathrm{~m}^{3} \cdot \mathrm{s}^{-1}\right)$. May $\left(3.08 \mathrm{~m}^{3} \cdot \mathrm{s}^{-1}\right)$ and $\mathrm{Au}$ gust $\left(2.06 \mathrm{~m}^{3} \cdot \mathrm{s}^{-1}\right)$ are the months which separate the flood periods. The average monthly values of water discharge from Besko reservoir over the year largely match the inflow values, which implies that the reservoir's discharge regime is shaped largely by the hydrological 
situation in the river drainage basin. The differences between the average monthly inflow and discharge values are minimal.

\section{Research methodology}

The analysis is based on the results of four series of measurements of water temperature in the longitudinal profile of the Wisłok in different hydrometeorological conditions in the annual cycle (4 August 2014, 15 November 2014, 5 March 2015 and 15 April 2015). Water temperature was measured along 47 kilometres of the river course between Puławy Górne and Krosno, in 3 locations upstream and 6 locations downstream of the reservoir and in one location on the reservoir surface near the dam (Fig. 1). The measurements of water temperature were taken with an electronic thermometer, near the river bank. Past water temperature measurements taken on rivers including the Ropa and the Dunajec (Gołek 1961; Cyberska 1972; Soja 1973; Wiejaczka 2011; Wiejaczka et al. 2014, 2015) had shown that, in mountain rivers with fast and often turbulent flow, measuring water temperatures at locations at intervals of several (up to 20) kilometres, depending on the local environment, is entirely sufficient for identifying temperature changes in the rivers' longitudinal profile. The constant mixing of water in such mountain rivers ensures even distribution of heat within the flowing water mass and therefore water temperature differences at distances of up to 2 to $3 \mathrm{~km}$ as well as in the river's transversal and vertical cross-sections do not exceed $1^{\circ} \mathrm{C}$ and are within measurement error.

Additionally, in order to explore the annual thermal patterns within the reservoir, affecting the temperature of the outflowing water, water temperature was also measured in a hydrometric vertical within the reservoir, near the dam, on the dates when measurements were carried out in the river profile. The measurements in the reservoir were taken using an electronic thermometer with a measurement plumb connected to the measuring device with a 55-metre long cable.
The measurements were taken at depth intervals of 1 metre from the surface towards the bottom.

Research of the Wisłok water temperature changes in the longitudinal profile of the river and temperature conditions within Besko reservoir was carried out in hydrometeorological conditions which were typical for each season during a year. The measurement results, as well as the analysis of results of past multi-annual observation series relating to other Carpathian rivers with reservoirs (Cyberska 1972, 1975; Soja 1973; Wiejaczka 2011; Wiejaczka et al. 2015), proved that four measurements taken in hydrometeorological conditions typical for the annual cycle were sufficient for a general identification of reservoir-attributable water temperature changes in the river's longitudinal profile as well as for the exploration of thermal condition dynamics within the reservoirs.

The findings of the field research were supplemented with an analysis of historical data made available by the Institute of Meteorology and Water Management, relating to the water gauge located in Krosno, at 147.9 km point of the river course, approx. $36 \mathrm{~km}$ downstream of Besko reservoir (Fig. 1). The data used in the study related to water temperature were based on measurements made in the hydrological years 1972 to 1983, at 6:00 UTC. That period was subdivided into two periods: before (1972-1977) and after (1978-1983) the commissioning of the Besko reservoir.

\section{Results and discussion}

\section{Annual water temperature dynamics in Besko reservoir}

At the time of the summer measurements of water temperature in Besko reservoir (on 4 August 2014), the ambient air temperature was $26.7^{\circ} \mathrm{C}$. The inflow to the reservoir was $2.7 \mathrm{~m}^{3} \cdot \mathrm{s}^{-1}$ and the discharge was $0.9 \mathrm{~m}^{3} \cdot \mathrm{s}^{-1}$. The water level in the reservoir was at $330.37 \mathrm{~m}$ a.s.l. (depth of $20 \mathrm{~m}$ ). The summer measurements did not clearly reveal a thermal stratification of the reservoir, i.e. the existence of three basic thermal strata 
across its vertical cross-section: the epilimnion (near the surface), the hypolimnion (near the bottom), and the thermocline, separating the two. The water temperature in the entire vertical was between $23.6^{\circ} \mathrm{C}$ near the surface and $15.6^{\circ} \mathrm{C}$ near the bottom (Fig. 2). In the entire vertical profile the average decrease of water temperature with depth was $0.4^{\circ} \mathrm{C} / 1 \mathrm{~m}$. The greatest temperature drop, of $2.5^{\circ} \mathrm{C}$, was observed already in the surface stratum, between 0 and 1 metre of depth. The stratum to the depth of 2 metres may be considered the epilimnion. Another marked drop of temperature (by $2.3^{\circ} \mathrm{C}$ ) was observed between 2 and 4 metres of depth (metalimnion). Further decrease of water temperature with the depth within the reservoir was minor, between 0 and $0.3^{\circ} \mathrm{C}$ per 1 metre. The depth of $4 \mathrm{~m}$ may be considered the upper limit of the hypolimnion (the stratum from which water is flowing out of the reservoir), with an average temperature of $17^{\circ} \mathrm{C}$.

At the time of the autumn measurements of water temperature in Besko reservoir (on 15 November 2014), the ambient air temperature was $8.4^{\circ} \mathrm{C}$. The inflow to the reservoir was $0.5 \mathrm{~m}^{3} \cdot \mathrm{s}^{-1}$ and the discharge was $0.9 \mathrm{~m}^{3} \cdot \mathrm{s}^{-1}$. The water level in the reservoir was at $331.58 \mathrm{~m}$ a.s.l. (depth of $21 \mathrm{~m}$ ). As evidenced by research carried out in other reservoirs in the Polish Carpathians (Cyberska 1975; Wiejaczka 2011; Soja \& Wiejaczka 2014; Wiejaczka et al. 2015), the autumn temperature pattern is characterised by relatively homogenous temperatures within the entire reservoir. It is a transitory stage between the summer stratification and the winter stratification. The temperature pattern observed in Besko reservoir on the measurement date was not a typical example of such homothermy but was close to it. The water temperature in the entire vertical was between $9.2^{\circ} \mathrm{C}$ near the surface and $8.4^{\circ} \mathrm{C}$ near the bottom (Fig. 2). In the entire vertical profile the average decrease of water temperature with depth was $0.04^{\circ} \mathrm{C} / 1 \mathrm{~m}$. Down to the depth of $18 \mathrm{~m}$, there was a slow decrease of temperature by a total of $1.8^{\circ} \mathrm{C}\left(0-0.5^{\circ} \mathrm{C} / 1 \mathrm{~m}\right)$. Below the depth of $18 \mathrm{~m}$, there was a clear increase of temperature with the depth, by $1.4^{\circ} \mathrm{C} / 3 \mathrm{~m}$, due to water cooling down more slowly in the bottom strata than in the strata located less deeply.

At the time of the winter measurements of water temperature in Besko reservoir (on 5 March 2015), the ambient air temperature was $1.7^{\circ} \mathrm{C}$. The inflow to the reservoir was $6.7 \mathrm{~m}^{3} \cdot \mathrm{s}^{-1}$ and the discharge was $4.4 \mathrm{~m}^{3} \cdot \mathrm{s}^{-1}$. The water level in the reservoir was at $331.68 \mathrm{~m}$ a.s.l. (depth of $21 \mathrm{~m}$ ). In winter, in the moderate climate zone, deep reservoirs normally reveal a reversed thermal stratification compared to the summertime. Research in Besko reservoir did not reveal the typical winter stratification, characterised by cooler water in the surface stratum and warmer in the bottom stratum. The water temperature in the entire vertical was within the narrow interval between $2.8^{\circ} \mathrm{C}$ near the surface and $3.1^{\circ} \mathrm{C}$ near the bottom (Fig. 2), demonstrating homothermy on the measurement date. A temperature variation of $0.1^{\circ} \mathrm{C}$ was only observed at the depth of $15 \mathrm{~m}$. A trace of the typical winter stratification was a scarcely noticeable increase of temperature by $0.3^{\circ} \mathrm{C}$ near the bottom. In Carpathian reservoirs, at the time of extremely low air temperatures and with ice cover presence, the difference in water temperature directly below the ice cover and near the bottom normally reaches $2-3^{\circ} \mathrm{C}$ (Wiejaczka 2011; Wiejaczka et al. 2014). A similar thermal stratification may be supposed to develop in Besko reservoir when completely covered with ice.

At the time of the spring measurements of water temperature in Besko reservoir (on 15 April 2015), the ambient air temperature was $13.2^{\circ} \mathrm{C}$. The inflow to the reservoir was $1.8 \mathrm{~m}^{3} \cdot \mathrm{s}^{-1}$ and the discharge was $7.9 \mathrm{~m}^{3} \cdot \mathrm{s}^{-1}$. The water level in the reservoir was at $331.38 \mathrm{~m}$ a.s.l. (depth of $21 \mathrm{~m}$ ). In spring, as in autumn, deep Carpathian reservoirs are characterised by homothermy as a transitory stage between winter stratification and summer stratification. The temperature pattern observed in Besko reservoir on the measurement date was not a typical example of such homothermy but was close to it. The water 


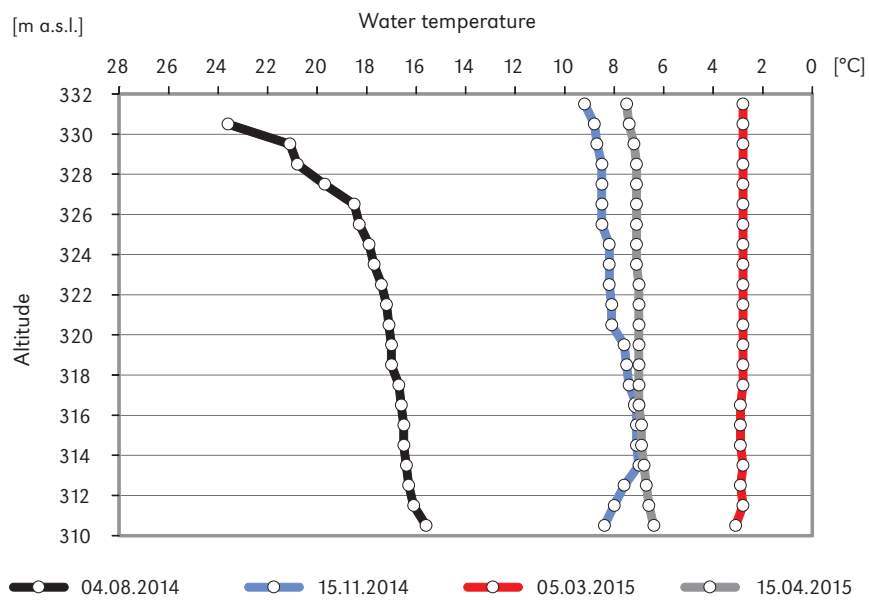

Figure 2. Water temperature in the vertical profile of Besko reservoir on the measurement dates

temperature in the entire vertical was between $7.5^{\circ} \mathrm{C}$ near the surface and $6.4^{\circ} \mathrm{C}$ near the bottom (Fig. 2). In the entire vertical profile the average decrease of water temperature with depth was $0.05^{\circ} \mathrm{C} / 1 \mathrm{~m}$.

\section{Annual variations of water temperature in the longitudinal profile of the Wisłok}

At the time of the summer measurements (Fig. 3), on 4 August 2014, the Wisłok water temperature upstream of Besko reservoir, between Puławy Dolne and Pastwiska, was between $24.8^{\circ} \mathrm{C}$ and $26.7^{\circ} \mathrm{C}$, with a slow upward trend. On the surface of the reservoir, the water temperature was similar, at $26.7^{\circ} \mathrm{C}$. Water flowing out of the reservoir (at the depth of $20 \mathrm{~m}$ ) was markedly cooler, at $16.5^{\circ} \mathrm{C}$. This was a result of the temperature pattern existing within the reservoir, as described in the previous section. Downstream of the reservoir, water was warming up very quickly: $100 \mathrm{~m}$ downstream of the dam, the water temperature had risen to as high as $20.2^{\circ} \mathrm{C}$, and $200 \mathrm{~m}$ further downstream, it was $21.5^{\circ} \mathrm{C}$. This was due to the shallow layer of water (up to $5 \mathrm{~cm}$ of depth) flowing over a concrete outflow surface heavily exposed to sunlight, downstream of the stilling basin. The water temperature growth further along the river course, although noticeable, was less rapid, at approx. $0.2^{\circ} \mathrm{C} / \mathrm{km}$ on average. At the end of the measurement profile, in Krosno, the water temperature was $27.5^{\circ} \mathrm{C}$.

At the time of the autumn measurements (Fig. 3), on 15 November 2014, the Wisłok water temperature both upstream and downstream from Besko reservoir was far more stable than in summer. Upstream of the reservoir, the river water temperature was $6.6-6.7^{\circ} \mathrm{C}$. It was significantly higher within the reservoir, in its surface layer $\left(9.2^{\circ} \mathrm{C}\right)$. On the other hand, water flowing from the deeper strata of the reservoir was cooler $\left(7.1^{\circ} \mathrm{C}\right)$ and its temperature was slightly decreasing with the river course downstream of the reservoir, down to $6.6^{\circ} \mathrm{C}$ in Krosno.

At the time of the winter measurements (Fig. 3) on 05 March 2015, the thermal longitudinal profile of the Wisłok revealed a clear division: upstream of the reservoir, the water was cooler (between 1.1 and $1.6^{\circ} \mathrm{C}$ ); downstream of it, it was warmer $\left(2 \cdot 8-4.2^{\circ} \mathrm{C}\right)$. It should be noted that during the hydrological year in which the measurements were taken, complete ice cover was never observed on the river upstream of the reservoir. At times when freezing ambient air temperatures continue for long periods and ice cover appears on the river and the reservoir, the temperature of inflowing water and that in the surface stratum of the reservoir normally decreases below $0.5^{\circ} \mathrm{C}$. 
Research conducted in the nearby Klimkówka reservoir on the Ropa river (Fig. 1) showed that the temperature of water flowing out of the reservoir in such hydrometeorological conditions is higher by 1 to 2 degrees Celsius than that of the inflowing water (Wiejaczka 2011). For the Wisłok, this was confirmed during additional research conducted in January 2017 (with the ambient air temperature of $-6.5^{\circ} \mathrm{C}$ ): the temperature of inflowing water was $0.2^{\circ} \mathrm{C}$, and that of the outflowing water was $2.3^{\circ} \mathrm{C}$. This means thermal stratification typical for the winter period having developed in Besko reservoir. In the case described above, after only several kilometres, the Wisłok water which had been warmed up by the reservoir cooled back down to the temperature observed upstream of the reservoir.

In the spring hydrometeorological conditions on 15 April 2015 (Fig. 3), Besko reservoir had a cooling effect on the Wisłok water. The temperature of water upstream of the reservoir was between $9.3^{\circ} \mathrm{C}$ and $10.7^{\circ} \mathrm{C}$ whereas the water in the reservoir was significantly cooler $\left(7.5^{\circ} \mathrm{C}\right.$ on the surface and $7.0^{\circ} \mathrm{C}$ in the outflow). Downstream of the reservoir, the water temperature increased rapidly over approx. $10 \mathrm{~km}$ of the river course, up to $13.6^{\circ} \mathrm{C}$. Further downstream, the Wisłok water cooled down by as much as $5^{\circ} \mathrm{C}$ and then the temperature remained fairly stable at $8-9^{\circ} \mathrm{C}$ down to the end of the measurement profile in Krosno.
The above analysis implies that the direction (increase or decrease) of the annual variations of the Wisłok water temperature directly downstream of Besko reservoir (15.01 million $\mathrm{m}^{3}$ ) is the same as in other Carpathian rivers downstream of larger reservoirs which have been subject to research to date, i.e. Klimkówka (43.5 million $\mathrm{m}^{3}$ ), the Czorsztyn-Sromowce Wyżne reservoir complex (232 million $\mathrm{m}^{3}$ and 7.5 million $\mathrm{m}^{3}$, respectively) and Rożnów-Czchów (193 million $\mathrm{m}^{3}$ and 12 million $\mathrm{m}^{3}$, respectively). In the summertime, the reservoir has a cooling effect on the river water whereas in winter it has a warming effect, as a result of the (summer or winter) thermal stratification of the water in the reservoir. Autumn and spring are transitory periods between the reservoir's cooling effect in summer and its warming effect in winter.

The scale of water temperature variations and the extent of Besko reservoir's effect on the Wisłok water annual temperature patterns diverge from those observed in other Polish Carpathian rivers downstream of reservoirs. The effect of Besko reservoir is observable at a much shorter length of the river course, from below 10 kilometres up to 20-30 km. At the distance of $36 \mathrm{~km}$ downstream of the Besko reservoir, its effect on the Wisłok water temperature is no longer discernible. The scale of the reservoir's effect on the Wisłok water temperature is not

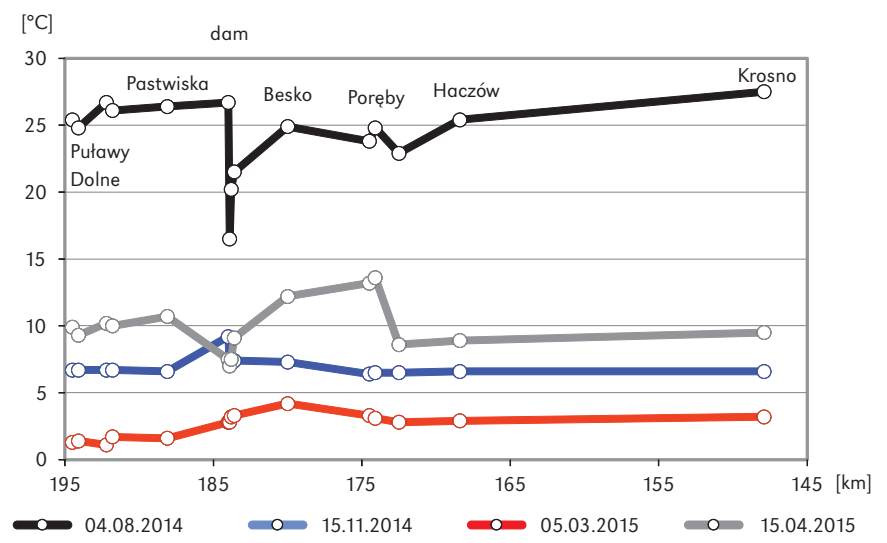

Figure 3. Water temperature in the longitudinal profile of the Wisłok between Puławy Dolne and Krosno 
great; the effect is largely eliminated at the short section of between 10 and 20 kilometres downstream of the dam.

\section{Evolution of the Wisłok thermal patterns downstream of Besko reservoir as revealed in the analysis of multiannual data}

A detailed analysis of the annual cycle of the Wisłok water temperature was conducted based on the daily water temperatures measured at the water gauge located in Krosno, at $147.9 \mathrm{~km}$ point of the river course (approx.
$36 \mathrm{~km}$ downstream of Besko reservoir) in the hydrological years 1975-1980.

An analysis of average monthly temperatures of the Wisłok water in three-year periods prior to (1975-1977) and following (1978-1980) the construction of Besko reservoir shows the pattern of water temperature decreasing markedly, except for some summer months when an increase of the water temperature was observed (Fig. 4). In the other Carpathian rivers with reservoirs on their course (the Dunajec, the Ropa) which were subject to analysis concerning the changes of their water temperature revealed in the archival data, the opposite
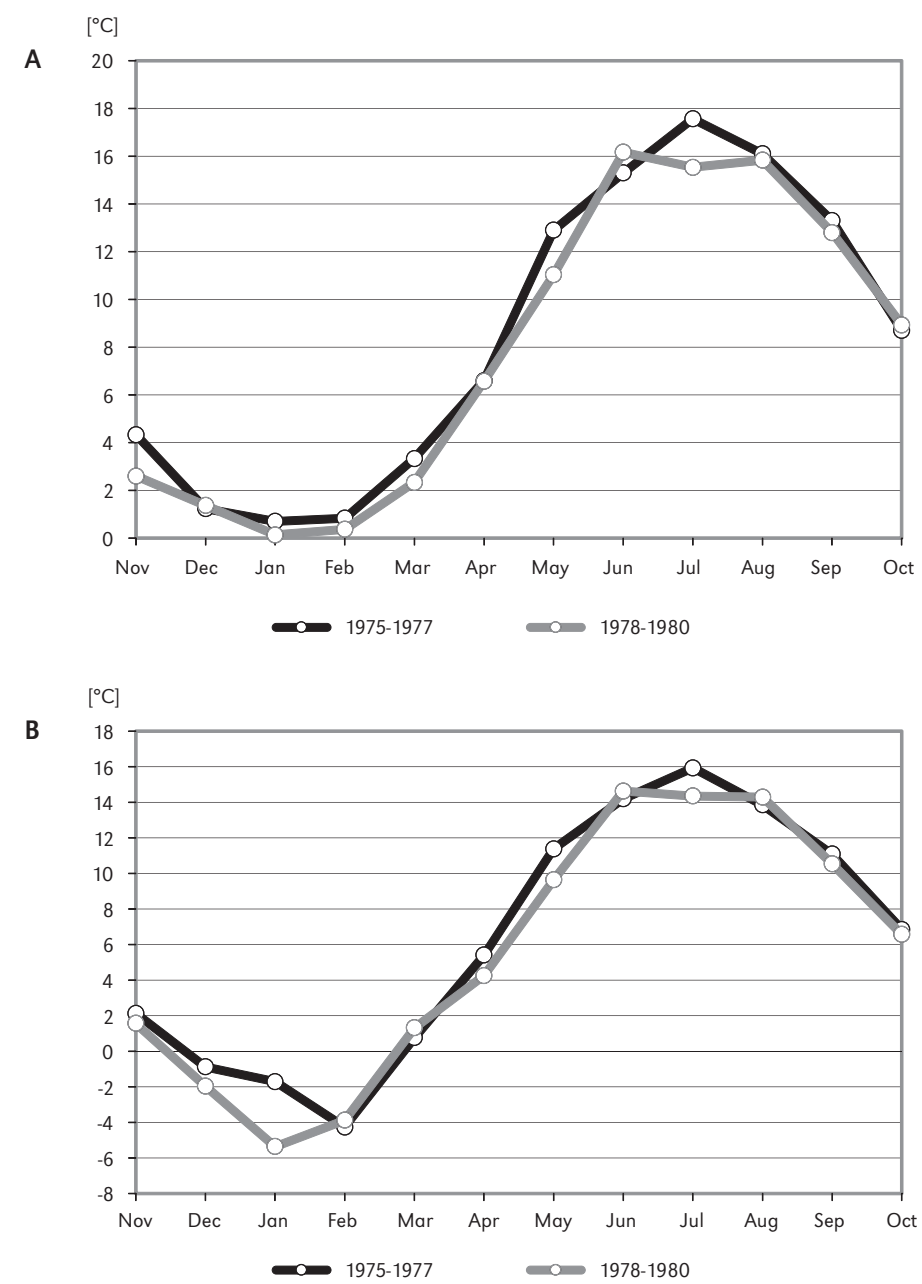

Figure 4. Average monthly temperatures of the Wisłok water (A) and air (B) temperatures in Krosno 
trend was observed (Cyberska 1972, 1975; Soja \& Wiejaczka 2014; Wiejaczka et al. 2015; Kędra \& Wiejaczka 2016). Following the creation of Klimkówka reservoir and the reservoir complexes Czorsztyn-Sromowce Wyżne and Rożnów-Czchów, the water temperature in rivers downstream of their locations decreased significantly in the summer periods and increased in winter. Those changes were very marked for measurement cross-sections located approx. 16 km downstream of Klimkówka reservoir (on the Ropa river) and 22 km downstream of the Czorsztyn-Sromowce Wyżne reservoir complex and $23 \mathrm{~km}$ downstream of the Rożnów-Czchów reservoir complex (on the Dunajec river). Research conducted in the longitudinal profile of the Ropa and the Dunajec shows that, with favourable hydrometeorological conditions, the reservoirs' effect on the water temperature is very well observable along tens of kilometres of the downstream river course, even as far as the river mouth (especially in summer, when the temperature variations in the rivers downstream of the dams are the most pronounced in the scale of the year).

The variation of the Wisłok water temperature in Krosno in the period following the construction of Besko reservoir corresponds to the variation of the air temperature (Fig. 4). A comparison of the average monthly temperatures of the Wisłok water and the ambient air temperatures between 1975 and 1977 and between 1978 and 1980 shows that the variation trends are similar. Each marked decrease in the ambient air temperature in successive months of the year is matched by a drop in the water temperature. Therefore, the variations of the Wisłok thermal regime in Krosno are not attributable to Besko reservoir but result from mesoclimate fluctuations in the area.

The above results are corroborated by an analysis of the natural and close relations between the Wisłok water temperatures and the ambient air temperatures. The correlation coefficient values between these variables, calculated for winter and summer hydrological half-year periods (between 1975 and 1980), clearly demonstrate their natural relation within the annual cycle throughout the study period (Fig. 5). The correlation between the river water temperature and the ambient air temperature is higher in the summertime than in the wintertime. The changes of river water temperatures attributable to the creation of reservoirs disturb these relations: after the reservoir is put to use, higher correlation coefficients are usually observed in winter and lower in summer. This is demonstrated by research conducted downstream of reservoirs on the Ropa and the Dunajec (Wiejaczka 2011; Soja \& Wiejaczka 2014; Kędra \& Wiejaczka 2016). No such reversal of water and air temperature relation in the annual cycle was observed for the Wisłok in Krosno.

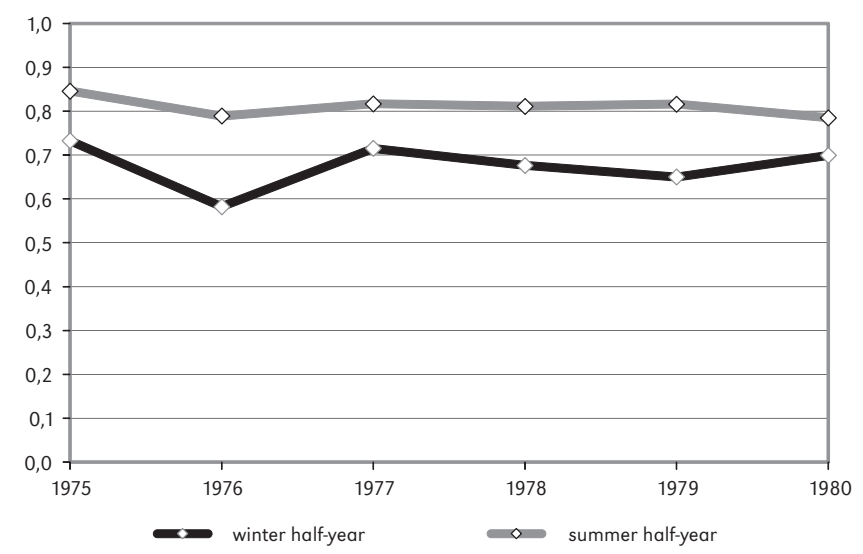

Figure 5. Correlation coefficients between water temperature in the Wisłok river and air temperature in Krosno 


\section{Conclusions}

The findings of the field research on the annual temperature of the Wisłok river and Besko reservoir, supplemented with the analysis of multiannual archival data on daily temperatures in the river downstream of the reservoir, allow the following conclusions to be drawn:

1. The creation of Besko reservoir in the upper course of the Wisłok has resulted in small changes in the longitudinal thermal profile of the river.

2. The cooling effect in summer and the warming effect in winter, observed in the river directly downstream of the reservoir, corresponds to the direction of effects observed in other Carpathian rivers downstream of large reservoirs.

3. The scale of the variation of water temperatures in summer is far smaller than observed in other Carpathian rivers downstream of larger reservoirs.

\section{References}

Allan J.D., Castillo M.M., 2007. Stream Ecology. Structure and function of running waters. Dordrecht: Springer.

ChOMIAK T., 1962. Wpływ zbiornika rożnowskiego na kształtowanie się temperatury wód Dunajca w odpływie ze zbiornika. Gospodarka Wodna Biuletyn PIHM, no. 1, pp. 33.

CyBersKa B., 1972. Zmiany w temperaturze i zlodzeniu rzek poniżej zbiorników retencyjnych. Gospodarka Wodna, no. 7, pp. 244-250.

CyberskA B., 1975. Wpływ zbiornika retencyjnego na transformację naturalnego reżimu termicznego rzeki. Prace IMGW, no. 4, pp. 45-108.

CAISSIE D., 2006. The thermal regime of rivers: a review. Freshwater Biology, vol. 51, no. 8, pp. 1389-1406.

DYNOWSKA I., 1971. Typy rezimów rzecznych w Polsce. Prace Instytutu Geograficznego UJ, no. 50, Prace Geograficzne, no. 28.

Frutiger A., 2004. Ecological impacts of hydroelectric power production on the River Ticino.
4. Besko reservoir affects the water temperature in a short section of the Wisłok, up to a maximum of 20 to $30 \mathrm{~km}$. At the measurement location in Krosno, $36 \mathrm{~km}$ downstream of Besko reservoir, its effect on the Wisłok water temperature is no longer discernible. The annual variations of the water temperature at that location is determined by the mesoclimate condition, mainly the ambient air temperature variations.

Based on the above conclusions concerning the effect of Besko reservoir on the Wisłok river water temperature, one may conclude that, unlike with much larger reservoirs in the Polish Carpathians, the environmental effects (in terms of thermal regime only) brought about by the construction of this hydrotechnical facility are of little significance.

Editors' note:

Unless otherwise stated, the sources of tables and figures are the authors', on the basis of their own research.

Part 2: Effects on the larval development of the dominant benthic macroinvertebrate (Allogamus auricollis, Trichoptera). Archiv für Hydrobiologie, vol. 159, no. 1, pp. 57-75.

Gotek J., 1961. Termika rzek polskich. Prace PIHM, no. 62 , pp. 1-79.

KĘDRA M., WiejacZKa $Ł ., ~ 2016$. Disturbance of water-air temperature synchronisation by dam reservoirs. Water and Environment Journal, vol. 30, no. 1-2, pp. 31-39.

LesSARD J.L., HaYes D.B., 2003. Effects of elevated water temperature on fish and macroinvertebrate communities below small dams. River Research and Applications, vol. 19, no. 7, pp. 721-732.

Liu B., Yang D., Ye B., Berezovskaya S., 2005. Longterm open-water season stream temperature variations and changes over Lena River Basin in Siberia. Global and Planetary Change, vol. 48, no. 1-3, pp. 96-111.

Olden J.D., Naiman R.J., 2010. Incorporating thermal regimes into environmental flows assessments: modifying dam operations to restore 
freshwater ecosystem integrity. Freshwater Biology, vol. 55, no. 1, pp. 86-107.

Punzet J., 1991. Wpływ zespołu zbiorników Rożnów - Czchów na reżim wodny Dunajca. Gospodarka Wodna, no. 6, pp. 122-126.

Soja R., 1973. Termika wody w dorzeczu Ropy $w$ okresie maksymalnych temperatur rocznych. Przeglad Geograficzny, vol. 54, no. 3, pp. 587-597.

SOJA R., WIEJACZKA Ł., 2014. The impact of a reservoir on the physicochemical properties of water in a mountain river. Water and Environment Journal, vol. 28, no. 4, pp. 473-482.

Tomik T., 1969. Próba charakterystyki termicznej zbiornika rożnowskiego. Prace PIHM, no. 96, pp. 43-55.

WebB B.W., Walling D.E., 1993. Temporal variability in the impact of river regulation on ther$\mathrm{mal}$ regime and some biological implications. Freshwater Biology, vol. 29, no. 1, pp. 167-182.
WIEJACZKA Ł., 2010. Zbiorniki retencyjne w polskich Karpatach. Aura, no. 10, pp. 7-9.

WiEjACZKA Ł., 2011. Wpływ zbiornika wodnego "Klimkówka" na abiotyczne elementy środowiska przyrodniczego w dolinie rzeki Ropy. Prace Geograficzne, 229, Warszawa: Instytut Geografii i Przestrzennego Zagospodarowania PAN.

Wiejaczka Ł., Kijowska-Strugata M., Pierwota P., NowaK M., 2014. Termiczna charakterystyka zespołu zbiorników Czorsztyn-Sromowce Wyżne. Gospodarka Wodna, no. 1, pp. 28-36.

Wiejaczka Ł., Kijowska-Strugata M., Pierwota P., Nowak M., 2015. Influence of the Czorsztyn-Sromowce Wyżne Reservoir Complex on the Dunajec River thermal-regime. Geographia Polonica, vol. 88, no. 3, pp. 467-482.

WiejACZKA Ł., WesOŁY K., 2012. Differentiation of temporal water level dynamics in the Besko and Klimkówka reservoirs (the Low Beskids, Poland). Geographia Polonica, vol. 85, no. 4, pp. 35-46.
(C) Łukasz Wiejaczka - Katarzyna Wesoły

(C) Geographia Polonica

(C) Institute of Geography and Spatial Organization

Polish Academy of Sciences - Warsaw • 2017
Article first received • January 2017

Article accepted • August 2017 